Article

\title{
Antioxidant Activity and Phenolic Composition of Amaranth (Amaranthus caudatus) during Plant Growth
}

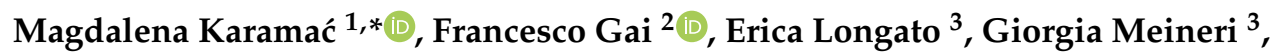 \\ Michał A. Janiak ${ }^{1}$, Ryszard Amarowicz ${ }^{1}$ (D) and Pier Giorgio Peiretti ${ }^{2}$ D \\ 1 Institute of Animal Reproduction and Food Research, Polish Academy of Sciences, Tuwima 10, \\ 10-748 Olsztyn, Poland; m.janiak@pan.olsztyn.pl (M.A.J.); r.amarowicz@pan.olsztyn.pl (R.A.) \\ 2 Institute of Sciences of Food Production, National Research Council, 10095 Grugliasco, Italy; \\ francesco.gai@ispa.cnr.it (F.G.); piergiorgio.peiretti@ispa.cnr.it (P.G.P.) \\ 3 Department of Veterinary Sciences, University of Turin, 10095 Grugliasco, Italy; erica.longato@unito.it (E.L.); \\ giorgia.meineri@unito.it (G.M.) \\ * Correspondence: m.karamac@pan.olsztyn.pl; Tel.: +48-895-234-622
}

Received: 15 May 2019; Accepted: 10 June 2019; Published: 12 June 2019

\begin{abstract}
The antioxidant activity and phenolic composition of the aerial part of Amaranthus caudatus at seven stages of development were investigated. Total phenolic content, $\mathrm{ABTS}^{\bullet+}$, $\mathrm{DPPH}^{\bullet}$, and $\mathrm{O}_{2}{ }^{\bullet-}$ scavenging activity, ferric-reducing antioxidant power (FRAP), and $\mathrm{Fe}^{2+}$ chelating ability were evaluated. The phenolic profile was characterized by 17 compounds. Rutin was predominant in all growth stages, although its content, similar to the quantity of other phenolics, changed during the growth cycle. Flavonols were most abundant in the plants of early flowering and grain fill stages. In contrast, the highest content of hydroxycinnamic acid derivatives was found in the early vegetative stage. The results of antioxidant assays also showed significant differences among plant stages. Generally, the lowest antioxidant activity was found in the shooting and budding stages. Significantly higher activity was observed in amaranths in earlier (vegetative) and later (early flowering and grain fill) stages, suggesting that plants in these stages are valuable sources of antioxidants.
\end{abstract}

Keywords: amaranth; morphological stage; scavenging activity; ferrous ions chelating ability; reducing power; phenolic compounds; rutin; growth cycle

\section{Introduction}

Amaranth (Amaranthus spp.) is a gluten-free pseudocereal that is cultivated primarily in Mexico and South America, but also thrives in all temperate-tropical areas of the world [1]. Moreover, in certain regions of the world, such as eastern Africa, amaranth leaves are consumed as a vegetable because it is a fast-growing plant available most of the year. There has been a renewed interest in this ancient and highly nutritious food crop due to the excellent nutritional value of seed and leaves [2-4]. Both seeds and leaves are rich sources of proteins, which constitute up to $15-43 \%$ and $14-30 \%$ of fresh matter (FM), respectively. Amaranth proteins have a well-balanced amino acid composition [4], high bioavailability [3], and good functional properties [5]. Dietary fiber, vitamins and precursors of vitamins (ascorbic acid, riboflavin, tocols, carotenoids), as well as minerals ( $\mathrm{Ca}, \mathrm{Fe}, \mathrm{Mg}, \mathrm{K}, \mathrm{Cu}, \mathrm{Zn}$, and $\mathrm{Mn}$ ) are other important nutrients present in seeds and leaves of amaranth. Their contents are high compared to these in some cereals and green leafy vegetables $[1,2,4]$. Nutrient composition causes an increasing interest in amaranth as a food ingredient, especially in the production of gluten-free products [6,7].

In addition to macro- and micronutrients, amaranth contains secondary plant metabolites, which may play a significant role in the human diet due to their potential health beneficial effects [8]. 
Considerable research has been conducted over the past years on phenolic compound profile of amaranth seeds [8-11] and their functional and bioactive properties [12-15]. However, recent findings confirmed that leaves and other aerial parts of Amaranthus also are important sources of phenolic compounds [16-18]. Among phenolic compounds, those belonging to hydroxycinnamic acids, benzoic acids, and flavonols and their glycosides were identified in amaranth leaves, flowers, and stalks $[18,19]$. Steffensen et al. [20] found additional hydroxycinnamyl amides in aerial parts of young plants. Phenolic compounds are well-known as antioxidants. Conforti et al. [21] showed that amaranth leaf extracts contained phenolics, inhibited nitric oxide production, and scavenged free radicals. The reducing potential and antioxidant activity in lipid systems of various parts of amaranth shoot system were determined as well $[16,19,22]$. Other phytochemicals with antioxidant activity which occur in amaranth are betalains, especially betacyanins [23]. The contents of these pigments vary among Amaranthus species and genotypes [24]. If they are present in the plant, they are accumulated mainly in seedlings, leaves, and inflorescences.

Although the phenolic compound and betacyanin profiles of individual botanical parts of amaranth as well as their antioxidant potential are well-known, information about effects of the growth cycle on these phytochemicals and their activity is still scarce. It is important to identify the changes in antioxidant activity and phenolic compound composition by the growth stage of the amaranth.

In a previous paper [25], we reported the nutritive characteristics of A. caudatus, and in particular, we evaluated the effects of plant aging on the chemical composition, gross energy, in vitro true digestibility, neutral detergent fiber digestibility and fatty acid profile. However, to the best of our knowledge, no research has been conducted to investigate the change of antioxidant activities and phenolic composition of extracts of $A$. caudatus during plant growth. Barba de la Rosa et al. [26] stated that the knowledge of Amaranthus spp. as a source of phytochemicals will increase their importance as a potential source of antioxidant compounds in the human diet.

The aim of this study was to compare the antioxidant activity, TPC, and individual phenolic compounds of $A$. caudatus during plant growth, to identify the ideal growing stage to achieve the maximum antioxidant properties, and to optimize its use as a source of antioxidants for use in food production.

\section{Materials and Methods}

\subsection{Chemicals}

The Folin-Ciocalteu phenol reagent (FCR), gallic acid, 2,2-diphenyl-1-picrylhydrazyl (DPPH), 2,2'-azinobis-(3-ethylbenzothiazoline-6-sulfonic acid) (ABTS), 2,4,6-tri(2-pyridyl)-s-triazine (TPTZ), 6-hydroxy-2,5,7,8-tetramethyl-chroman-2-carboxylic acid (Trolox), ferrozine, caffeic acid, quercetin, p-coumaric acid, ferulic acid, rutin, and kaempferol-3-O-rutinoside were obtained from Sigma-Aldrich (St. Louis, MO, USA). Methanol, acetonitrile, sodium carbonate, ferric chloride, ferrous chloride, ferrous sulfate, and potassium persulfate were acquired from Avantor Performance Materials (Gliwice, Poland). The ACL kit was purchased from Analytik Jena (Jena, Germany).

\subsection{Plant Material}

A. caudatus seeds were generously donated by Pedon S.p.A. (Molvena, Italy). The amaranth stands were seeded in the spring in field trials (Department of Veterinary Science of the University of Turin) located in Grugliasco, Piedmont, NW Italy ( $293 \mathrm{~m}$ a.s.l., $45^{\circ} 03^{\prime} 57.9^{\prime \prime} \mathrm{N} 7^{\circ} 35^{\prime} 36.9^{\prime \prime} \mathrm{E}$ ), and no irrigation or fertilizers were applied after sowing. The herbage samples were collected in the morning after evaporation of dew and never collected on rainy days. Sampling was performed according to Peiretti et al. [25] at seven progressive morphological stages from early vegetative to grain fill stage from May to July 2014. Plants were cut to a 1-2 cm stubble height with edging shears from two replicate $2 \mathrm{~m}^{2}$ subplots randomly located in $2 \times 7 \mathrm{~m}^{2}$ plots. 


\subsection{Extraction}

Plant samples were lyophilized (FreeZone Freeze Dry System, Labconco, Kansas City, MO, USA) and ground. Three-gram portions of materials were suspended in $30 \mathrm{~mL}$ of $80 \%(v / v)$ methanol. The closed bottles containing suspensions were shaken for $15 \mathrm{~min}$ in a water bath (SW22, Julabo, Seelbach, Germany) at $65^{\circ} \mathrm{C}$. After filtration, the residues were extracted twice more. Combined filtrates for each sample were dried by evaporation of methanol under vacuum at $50{ }^{\circ} \mathrm{C}$ (Rotavapor R-200, Büchi Labortechnik, Flawil, Switzerland) and lyophilization of remaining water. Yield of extraction (\%) was calculated on the basis of weight of plant sample and dry extract.

\subsection{Total Phenolic Content}

The colorimetric reaction with FCR was carried out to determinate the total phenolic content (TPC) [27]. The $0.25 \mathrm{~mL}$ of extract solution in methanol $(1.25 \mathrm{mg} / \mathrm{mL}), 0.25 \mathrm{~mL}$ of FCR, $0.5 \mathrm{~mL}$ of saturated sodium carbonate solution, and $4 \mathrm{~mL}$ of water were mixed. After $25 \mathrm{~min}$, the reaction mixtures were centrifuged (5 min, 5000× $g$, MPW-350R, MPW Med. Instruments, Warsaw, Poland), and the absorbance of supernatants was measured at $725 \mathrm{~nm}$ (DU-7500 spectrophotometer, Beckman Instruments, Fullerton, CA, USA). TPC was expressed as gallic acid equivalents (GAE) per $\mathrm{g}$ of extract or per $\mathrm{g}$ of FM of plant.

\subsection{Trolox Equivalent Antioxidant Capacity}

The Trolox equivalent antioxidant capacity (TEAC) was determined according to the assay reported by Re et al. [28]. ABTS ${ }^{\bullet+}$ was generated and diluted as in the original description. Next, solutions of $\mathrm{ABTS}^{\bullet+}(2 \mathrm{~mL})$ and amaranth extracts $(20 \mu \mathrm{L}$ with a concentration of $2.5 \mathrm{mg} / \mathrm{mL})$ were vortexed and heated at $30^{\circ} \mathrm{C}$ (TH-24 block heater, Meditherm, Warsaw, Poland) within 6 min. After incubation, absorbance was measured at $734 \mathrm{~nm}$ (DU-7500 spectrophotometer). The results were expressed as $\mu \mathrm{mol}$ Trolox equivalents (TE) per $\mathrm{g}$ of extract or per $\mathrm{g}$ of FM of plant.

\subsection{Ferric-Reducing Antioxidant Power}

The Benzie and Strain method [29] was used to evaluate the ferric-reducing antioxidant power (FRAP) of amaranth extracts. First, FRAP reagent was prepared. Next, the portions of $2.25 \mathrm{~mL}$ of this reagent were mixed with $225 \mu \mathrm{L}$ of water and $75 \mu \mathrm{L}$ of aqueous solution of amaranth extracts $(1 \mathrm{mg} / \mathrm{mL})$. Absorbance of mixtures was recorded at $593 \mathrm{~nm}$ after incubation at $37^{\circ} \mathrm{C}$ for $30 \mathrm{~min}$. FRAP results were expressed as $\mu \mathrm{mol} \mathrm{Fe}^{2+}$ equivalents per $\mathrm{g}$ of extract or per $\mathrm{g}$ of $\mathrm{FM}$ using the calibration curve for $\mathrm{FeSO}_{4}$.

\subsection{Photochemiluminescence Assay}

In the photochemiluminescence (PCL) assay, superoxide radical anions $\left(\mathrm{O}_{2}{ }^{\bullet-}\right)$ were generated from luminol [30]. The antiradical activity against these radicals was determined using the ACL (antioxidant capacity of lipid-soluble substances) kit (Analytik Jena, Jena, Germany). The amaranth extracts were dissolved in methanol to a concentration of $0.25 \mathrm{mg} / \mathrm{mL}$. The portions of $10 \mu \mathrm{L}$ of solutions were mixed with $2.3 \mathrm{~mL}$ of methanol (reagent 1), $200 \mu \mathrm{L}$ of buffer solution (reagent 2), and $25 \mu \mathrm{L}$ of luminol (reagent 3). The Photochem device (Analytik Jena) supported by PCLsoft software was used to perform reactions and calculate the results, which were expressed as $\mu$ mol of Trolox equivalents (TE) per $g$ of extract or per $g$ of FM of plant.

\section{8. $\mathrm{Fe}^{2+}$ Chelating Ability}

The ability of amaranth extracts to chelate ferrous ions was determined by a method with ferrozine [31] that was modified to be performed with multi-well plates [32]. Extract solution in water $(0.25 \mathrm{mg} / \mathrm{mL}), 0.4 \mathrm{mM} \mathrm{FeCl}_{2} \times 4 \mathrm{H}_{2} \mathrm{O}$ and $5 \mathrm{mM}$ ferrozine were mixed in a ratio of 10:1:2 (v/v/v). After $10 \mathrm{~min}$, absorbance was measured at $562 \mathrm{~nm}$ using an Infinite M1000 microplate reader (Tecan, Männedorf, Switzerland). The chelating ability was expressed as percentage of $\mathrm{Fe}^{2+}$ bound. 


\subsection{Scavenging of the DPPH Radicals}

The $\mathrm{DPPH}^{\bullet}$ scavenging activity of amaranth extracts was evaluated by the method of Brand-Williams et al. [33]. Extract solutions in methanol over a range of concentrations from $2-10 \mathrm{mg} / \mathrm{mL}$ were prepared. To $100 \mu \mathrm{L}$ of these solutions, $0.25 \mathrm{~mL}$ of $1 \mathrm{mM} \mathrm{DPPH}$ and $2 \mathrm{~mL}$ of methanol were added. After $20 \mathrm{~min}$, absorbance of the mixtures was read at $517 \mathrm{~nm}$. The curves of absorbance values vs. concentration of samples (mg/assay) were plotted. Additionally, $\mathrm{EC}_{50}$ values defined as concentration of extract $(\mathrm{mg} / \mathrm{mL}$ reaction mixture) needed to scavenge the $50 \%$ of initial $\mathrm{DPPH}^{\bullet}$ were evaluated.

\subsection{Analysis of Phenolic Compounds}

The HPLC-DAD Shimadzu system (Shimadzu, Kioto, Japan), which consisted of a CBM-20A controller, DGU-20A5R degassing unit, two LC-30AD pumps, SIL-30AC autosampler, SPD-M30A diode array detector (DAD), and CTO-20AC oven, was used to analyze the phenolic compound of the amaranth extracts. Extracts dissolved in $80 \%(v / v)$ methanol were injected $(10 \mu \mathrm{L})$ into a Luna C8(2) $(4.6 \times 150 \mathrm{~mm}$, particle size $3 \mu \mathrm{m}$, Phenomenex, Torrance, CA, USA) column [34]. The mobile phase consisted of solvents A (acetonitrile-water-trifluoroacetic acid, 5:95:0.1, v/v/v) and B (acetonitrile-trifluoroacetic acid, 100:0.1, v/v): From 0-16 min, the eluent composition was changed from 0-24\% B. The flow rate was $1 \mathrm{~mL} / \mathrm{min}$. The oven temperature was $25^{\circ} \mathrm{C}$ and detector wavelength ranged from 200 to 600 $\mathrm{nm}$. The content of individual phenolic compounds in the extracts was expressed on the basis of a calibration curve of the corresponding standards or structurally related substances.

For identification of extract compounds, HPLC-MS/MS analysis was carried out using a liquid chromatography (LC) system coupled with a quadrupole ion trap mass spectrometer $\left(Q^{2}\right.$ RAP $^{\circledR}$ 5500 LC-MS/MS System, AB Sciex, Framingham, MA, USA). Operating MS/MS conditions were the following: Nitrogen curtain gas flow rate of $25 \mathrm{~L} / \mathrm{min}$, collision gas glow rate of $9 \mathrm{~L} / \mathrm{min}$, ion spray source voltage of $-4.5 \mathrm{kV}$, temperature of $350{ }^{\circ} \mathrm{C}$, nebulizer gas flow rate of $35 \mathrm{~L} / \mathrm{min}$, and turbo gas flow rate of $30 \mathrm{~L} / \mathrm{min}$. Negative-mode of electrospray ionization $\left(\mathrm{ESI}^{-}\right)$was used. Qualification was based on multiple reaction monitoring (MRM) of selected ion pairs in the first quadrupole (Q1) and third quadrupole (Q3). The presence of compounds previously identified in aerial parts of amaranth $[10,18-20,35]$ were verified.

\subsection{Statistical Analysisl}

The plant growth experiment was carried out in duplicate. Antioxidant assays and HPLC-DAD separations were performed for at least three repetitions. All results were presented as means \pm standard deviations (SD). Significance of differences among mean values were estimated by one-way ANOVA and Fisher's LSD test at a level of $p<0.05$ (GraphPad Prism; GraphPad Software, San Diego, CA, USA). Principal component analysis (PCA) allowed examination of the relationships between TPC, individual phenolic compound contents and values of antioxidant assays obtained for amaranth at different growth stages.

\section{Results and Discussion}

\subsection{Total Phenolic Content}

The extraction yield and TPC of the aerial parts of amaranth at different growth stages, expressed on the basis of both extract and fresh matter, are reported in Table 1. The extraction yield did not differ statistically $(p \geq 0.05)$ for plants in vegetative, shooting and budding stages, while lower values were recorded for early flowering and grain fill stages of amaranth. The TPC ranged from 18.3 to $33.7 \mathrm{mg} \mathrm{GAE} / \mathrm{g}$ extract. TPC expressed on the basis of plant fresh matter was in the range of 0.68 to $1.11 \mathrm{mg} / \mathrm{g}$. The highest values were observed in the earliest (early and medium vegetative) and the oldest (early flowering and grain fill) stages of plant. The lowest TPC was noted for extracts obtained from the shooting and budding stages. Li et al. [19] compared phenolic contents of different botanical 
parts of three Amaranthus species (A. hypochondriacus, A. caudatus, and A. cruentus) and found that the leaves had the highest TPC while the seeds and stalks contained the lowest. Therefore, in our study, the high TPC levels found in the amaranth of vegetative stages could be related to the major proportion of leaves with respect to stalks present in these plant growth stages compared to the others. A similar trend was reported in other pseudocereals, such as quinoa [36], as well as soybean [32], where authors found that extracts obtained from the early and late vegetative stages were characterized by the highest TPC. The TPC of amaranth extract of early flowering stage plants presented in Table 1 was in agreement with those reported for methanol-water and acetone extracts from separate leaves (24.8-32.3 mg GAE/g extract) and flowers (27.2-33.3 mg GAE/g extract) collected from a flowering stage of $A$. hybridus [16]. In turn, higher TPC (2.9 mg GAE/g FM) was noted for the five-week-old A. caudatus leaves [26] corresponding to an intermediate between early and medium vegetative stages in our study.

Table 1. Yield of extraction and total phenolic content (TPC) of the amaranth extract and fresh matter (FM) in different growth stages.

\begin{tabular}{ccccc}
\hline \multirow{2}{*}{ Growth Stage } & \multirow{2}{*}{$\begin{array}{c}\text { Time after } \\
\text { Seeding (days) }\end{array}$} & Extraction & \multicolumn{2}{c}{ TPC } \\
\cline { 4 - 5 } & & & & \multicolumn{2}{c}{ Yield (\%) } & mg GAE/g Extract & mg GAE/g FM \\
\hline Early vegetative & 34 & $24.3 \pm 0.3^{\mathrm{ab}}$ & $33.7 \pm 4.5^{\mathrm{a}}$ & $0.94 \pm 0.14^{\mathrm{abc}}$ \\
Medium vegetative & 41 & $26.3 \pm 3.2^{\mathrm{a}}$ & $31.1 \pm 3.5^{\mathrm{ab}}$ & $1.04 \pm 0.05^{\mathrm{ab}}$ \\
Late vegetative & 55 & $27.4 \pm 0.6^{\mathrm{a}}$ & $27.9 \pm 0.4^{\mathrm{b}}$ & $0.81 \pm 0.03^{\mathrm{bcd}}$ \\
Shooting & 62 & $26.7 \pm 0.5^{\mathrm{a}}$ & $18.6 \pm 2.9^{\mathrm{c}}$ & $0.68 \pm 0.16^{\mathrm{d}}$ \\
Budding & 69 & $26.6 \pm 0.4^{\mathrm{a}}$ & $18.3 \pm 3.4^{\mathrm{c}}$ & $0.71 \pm 0.15^{\mathrm{cd}}$ \\
Early flowering & 74 & $22.7 \pm 0.5^{\mathrm{bc}}$ & $27.4 \pm 0.6^{\mathrm{ab}}$ & $1.11 \pm 0.03^{\mathrm{a}}$ \\
Grain fill & 78 & $20.3 \pm 1.7^{\mathrm{c}}$ & $27.3 \pm 3.5^{\mathrm{ab}}$ & $0.88 \pm 0.07^{\mathrm{abc}}$ \\
\hline
\end{tabular}

GAE, gallic acid equivalents. ${ }^{\text {abcd }}$ Means with the different lowercase letters in the same column are significantly different $(p<0.05)$.

\subsection{Antioxidant Activity}

The antioxidant activity of amaranth samples of each growth stage was determined as radical scavenging activity (TEAC, PCL-ACL, and DPPH assay) and ability to reduce $\mathrm{Fe}^{3+}$ to $\mathrm{Fe}^{2+}$ (FRAP). Additionally, $\mathrm{Fe}^{2+}$ chelating ability of extracts was determined because phenolic compounds form stable complexes with ferrous ions, and in this way, decrease the extent of free ions to Fenton's reaction in which highly reactive ${ }^{\bullet} \mathrm{OH}$ are generated [31]. The results of antioxidant activity are presented in Table 2 and Figures 1 and 2. The significantly higher TEAC was recorded for amaranth in vegetative, early flowering and grain fill stages as opposed to in shooting and budding stages $(p<0.05)$, both when results were expressed on the basis of extract and fresh matter of plant. The FRAP ranged from 469 to $830 \mu \mathrm{mol} \mathrm{Fe}{ }^{2+} / \mathrm{g}$ extract with the highest value observed for the early vegetative stage and the lowest, again, for the shooting and budding stages of the plant. The FRAP expressed on plant fresh matter basis was less varied between amaranth growth stages (17.4-24.6 $\left.\mu \mathrm{mol} \mathrm{Fe}{ }^{2+} / \mathrm{g}\right)$. The PCL-ACL ranged from 422 to $858 \mu \mathrm{mol}$ TE/g extract and from 16.5 to $23.9 \mu \mathrm{mol}$ TE/g FM, respectively. For both types of PCL-ACL expression, amaranth in vegetative stages had significantly higher activity compared to plants in subsequent morphological states $(p<0.05)$. In turn, the $\mathrm{Fe}^{2+}$ chelating ability of extracts ranged from $16.1-19.9 \%$ for late vegetative and shooting stages to $37.5 \%$ for the medium vegetative stage (Figure 1). The changes of antiradical activity against DPPH ${ }^{\bullet}$ of amaranth extracts with increasing assay content as well as the $\mathrm{EC}_{50}$ values, are presented in Figure 2 . The DPPH${ }^{\bullet}$ scavenging activity expressed as $\mathrm{EC}_{50}$ showed significant differences between certain growth stages of amaranth $(p<0.05)$. The highest antiradical activity was obtained for extracts from plants in the early flowering and grain fill stages with the lowest $\mathrm{EC}_{50}$ value. The highest $\mathrm{EC}_{50}$ values $(294-317 \mu \mathrm{g} / \mathrm{mL})$, which did not differ statistically from each other $(p \geq 0.05)$, were found for late vegetative, shooting, and budding stages.

To the best of our knowledge, the changes of antioxidant activity of amaranth aerial parts during the growth cycle have not been previously demonstrated, although the differences in the antioxidant 
potential of various morphological parts of the plant were shown [16,19,37]. In general, FRAP, DPPH ${ }^{\bullet}$, or $\mathrm{ABTS}^{\bullet+}$ scavenging capacity decreased in this order: Leaves $\geq$ flowers $>>$ stem $>$ seeds. Among some amaranth species, this relationship was demonstrated for A. caudatus [19]. It is known that environmental factors, such as light and temperature, also play an important role in amaranth antioxidant metabolism. Khandaker et al. [38] found that the antioxidant activity of leaves of red amaranth (A. tricolor) was higher under full sunlight intensity than under dark conditions. Modi [39] studied the effect of growth temperature on yield, nutritional value, and antioxidant activity of the leaves of five Amaranthus spp. (A. hybridus var. cruentus, A. hypochondriacus, A. tricolor, A. thunbergii, and A. hybridus) harvested at 20, 40, and 60 days after sowing and found significant differences between growth temperature and stage of development. Authors concluded that for greater nutritional benefit, Amaranthus should be grown under warm conditions and that younger leaves are preferable. The maximum antioxidant activity, independent of the temperature and species considered, was found in leaves after 60 days of sowing, corresponding to an intermediate stage between late vegetative and shooting found in our study.

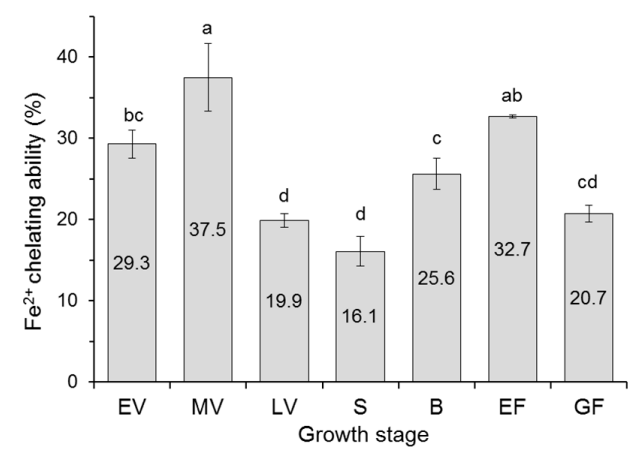

Figure 1. $\mathrm{Fe}^{2+}$ chelating ability of the amaranth extracts. $\mathrm{EV}$, early vegetative; $\mathrm{MV}$, medium vegetative; LV, late vegetative; S, shooting; B, budding; EF, early flowering; GF, grain fill. Different letters above bars indicate significant differences among means $(p<0.05)$.
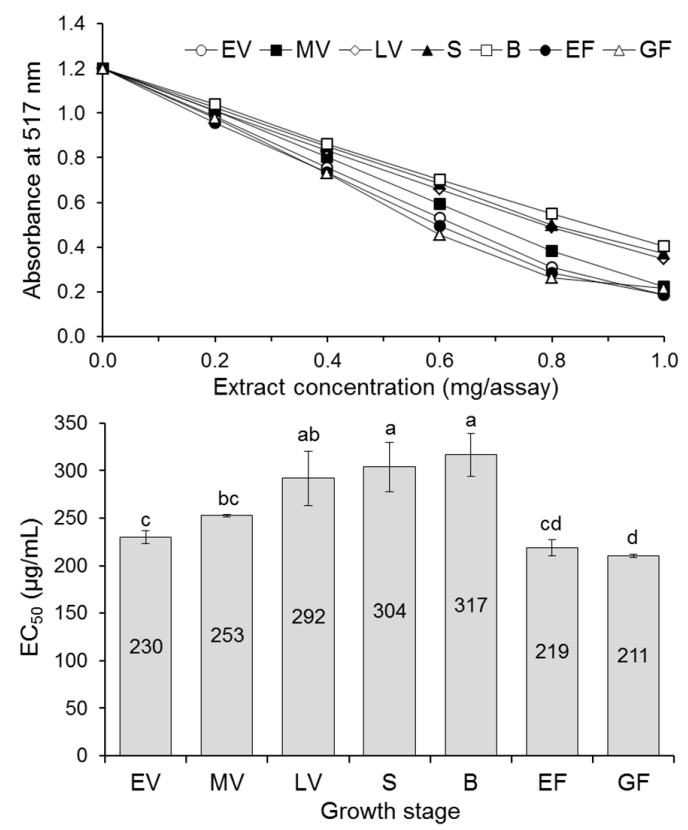

Figure 2. DPPH ${ }^{\bullet}$ scavenging activity of the amaranth extracts. EV, early vegetative; $\mathrm{MV}$, medium vegetative; $\mathrm{LV}$, late vegetative; $\mathrm{S}$, shooting; $\mathrm{B}$, budding; $\mathrm{EF}$, early flowering; $\mathrm{GF}$, grain fill. Different letters above bars indicate significant differences among means $(p<0.05)$. 
Table 2. Antioxidant activity of the amaranth extract and fresh matter (FM) in different growth stages.

\begin{tabular}{|c|c|c|c|c|c|c|}
\hline \multirow{2}{*}{ Growth Stage } & \multicolumn{2}{|c|}{ TEAC } & \multicolumn{2}{|c|}{ FRAP } & \multicolumn{2}{|c|}{ PCL-ACL } \\
\hline & $\begin{array}{c}\mu \mathrm{mol} \mathrm{TE} / \mathrm{g} \\
\text { Extract }\end{array}$ & $\begin{array}{c}\mu \mathrm{mol} \mathrm{TE} / \mathrm{g} \\
\text { FM }\end{array}$ & $\begin{array}{c}\mu \mathrm{mol} \mathrm{Fe} \mathrm{Fe}^{2+} / \mathrm{g} \\
\text { Extract }\end{array}$ & $\begin{array}{c}\mu \mathrm{mol} \mathrm{Fe}{ }^{2+} / \mathrm{g} \\
\mathrm{FM}\end{array}$ & $\begin{array}{c}\mu \mathrm{mol} \mathrm{TE} / \mathrm{g} \\
\text { Extract }\end{array}$ & $\begin{array}{c}\mu \mathrm{mol} \mathrm{TE} / \mathrm{g} \\
\text { FM }\end{array}$ \\
\hline Early vegetative & $259 \pm 27^{a b}$ & $7.23 \pm 0.91 \mathrm{bc}$ & $830 \pm 27^{a}$ & $23.1 \pm 1.3^{\mathrm{ab}}$ & $858 \pm 24^{a}$ & $23.9 \pm 1.2^{a}$ \\
\hline Medium vegetative & $283 \pm 27^{a}$ & $9.52 \pm 0.34^{\mathrm{a}}$ & $65 \pm 83^{b}$ & $22.3 \pm 1.5^{\mathrm{ab}}$ & $698 \pm 43^{b}$ & $23.6 \pm 2.8^{\mathrm{a}}$ \\
\hline Late vegetative & $272 \pm 18^{a b}$ & $8.58 \pm 0.38^{a b}$ & $648 \pm 25^{b}$ & $20.4 \pm 1.2^{\mathrm{abc}}$ & $681 \pm 42^{b}$ & $21.5 \pm 1.8^{\mathrm{ab}}$ \\
\hline Shooting & $176 \pm 6.0^{c}$ & $6.44 \pm 0.69^{c}$ & $475 \pm 31^{c}$ & $17.4 \pm 2.4^{\mathrm{c}}$ & $486 \pm 3.9^{\mathrm{cd}}$ & $17.8 \pm 1.4^{b c}$ \\
\hline Budding & $171 \pm 8.1^{\mathrm{c}}$ & $6.67 \pm 0.5$ & $469 \pm 75^{c}$ & $18.3 \pm 3.5^{b c}$ & $422 \pm 43^{d}$ & $16.5 \pm 2.2^{c}$ \\
\hline Early flowering & $218 \pm 23$ bc & $8.83 \pm 0.87^{a b}$ & $606 \pm 15^{b c}$ & $24.6 \pm 0.4^{\mathrm{a}}$ & $483 \pm 20 \mathrm{~cd}$ & $19.6 \pm 0.7 \mathrm{bc}$ \\
\hline Grain fill & $236 \pm 45^{a b}$ & $7.62 \pm 1.13^{b c}$ & $640 \pm 112^{b}$ & $20.7 \pm 2.7 \mathrm{abc}$ & $558 \pm 34^{c}$ & $18.1 \pm 0.3^{b c}$ \\
\hline
\end{tabular}

TEAC, Trolox equivalent (TE) antioxidant capacity; FRAP, ferric-reducing antioxidant power; PCL-ACL, photochemiluminescence-antioxidant capacity of lipid-soluble substances. ${ }^{\text {abcd }}$ Means with the different lowercase letters in the same column are significantly different $(p<0.05)$.

\subsection{Phenolic Compound Profile}

The HPLC-DAD analysis showed that the phenolic profile was characterized by 17 compounds (Figure 3). The absorption maxima of UV-Vis spectra of compounds and MRM Q1/Q3 ion pairs used for their identification are listed in Table 3. Compounds 10, 13, and 17 were identified as caffeic acid, rutin, and kaempferol-3-O-rutinoside, respectively, by comparison with standards. Their presence in the extracts was confirmed by HPLC-MS/MS analysis. This analysis allowed also showing the presence of twelve hydroxycinnamic acids (1-12) and quercetin glucoside (15) in the extracts. Two other compounds (14 and 16) were tentatively identified as hydroxycinnamic acid derivatives based on the shape of UV spectra with maxima absorption at 315-329 nm and a shoulder at the shorter wavelength [34]. Most of the identified compounds (caffeic acid, caffeoyl-, coumaroyl- and feruloylglucaric isomers, feruloyl- and caffeoyl- quinic acids, rutin, kaempferol-3-O-rutinoside, and quercetin glucoside) were detected previously in leaves, seeds, and other aerial parts of $A$. caudatus [10,18-20]. Coumaroylquinic acids were found in stems of $A$. spinosus [35]. In turn, the free phenolic acids, such as, ferulic, $p$-coumaric, $p$-hydroxybenzoic, vanillic, sinapic, gallic, and protocatechuic acids, as well as betacyanins, were not identified in amaranth in the present study, although, according to literature data, they were determined in leaves, flowers, stalks and seeds of $A$. caudatus $[10,11,19,40]$. The lack of identification of betacyanins in our samples probably results from the selection of the betacyanin-free A. caudatus genotype for experiments.

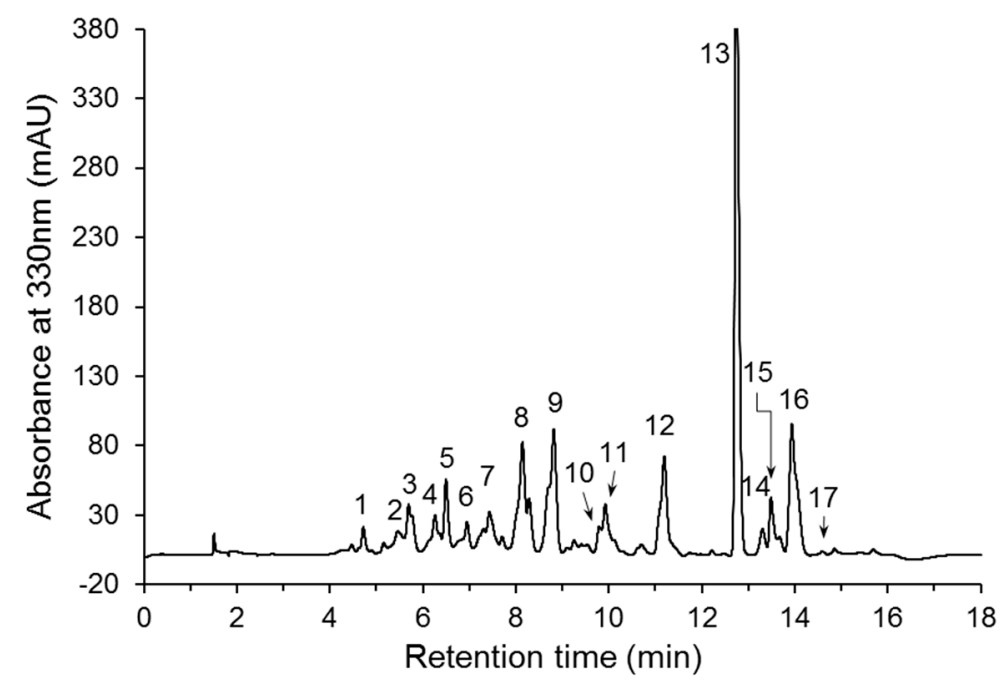

Figure 3. HPLC-DAD chromatogram of the phenolic compounds present in the amaranth extract. 
Table 3. Chromatographic and spectral data of the phenolic compounds identified in amaranth extracts.

\begin{tabular}{|c|c|c|c|c|}
\hline $\begin{array}{l}\text { Compound } \\
\text { No }^{1}\end{array}$ & $t_{R}(\min )^{2}$ & $\lambda_{\max }(\mathrm{nm})^{3}$ & $\begin{array}{c}\text { Ion Pair }{ }^{4} \\
\text { (Q1/Q3) }\end{array}$ & Compound \\
\hline 1 & 4.80 & 301sh;327 & $371 / 209 ; 371 / 173$ & Caffeoylglucaric acid 1 \\
\hline 2 & 5.52 & 301sh;327 & $371 / 209 ; 371 / 173$ & Caffeoylglucaric acid 2 \\
\hline 3 & 5.75 & $302 \mathrm{sh} ; 327$ & $371 / 209 ; 371 / 173$ & Caffeoylglucaric acid 3 \\
\hline 4 & 6.31 & $302 \mathrm{sh} ; 328$ & $371 / 209 ; 371 / 173$ & Caffeoylglucaric acid 4 \\
\hline 5 & 6.54 & $303 \mathrm{sh} ; 328$ & $371 / 209 ; 371 / 173$ & Caffeoylglucaric acid 5 \\
\hline 6 & 6.95 & $304 \mathrm{sh} ; 327$ & $371 / 191 ; 371 / 209$ & Coumaroylglucaric acid 1 \\
\hline 7 & 7.47 & 304 sh; 327 & $371 / 191 ; 371 / 209$ & Coumaroylglucaric acid 2 \\
\hline 8 & 8.18 & $299 \mathrm{sh} ; 326$ & $385 / 191 ; 385 / 209$ & Feruloylglucaric acid \\
\hline 9 & 8.84 & $303 \mathrm{sh} ; 327$ & $353 / 191 ; 353 / 173$ & Caffeoylquinic acid \\
\hline 10 & 9.78 & 296 sh; 324 & $179 / 135 ; 179 / 107$ & Caffeic acid \\
\hline 11 & 9.93 & $301 \mathrm{sh} ; 314$ & $337 / 173 ; 337 / 155$ & Coumaroylquinic acid \\
\hline 12 & 11.21 & $304 \mathrm{sh} ; 329$ & $367 / 173 ; 367 / 155$ & Feruloylquinic acid \\
\hline 13 & 12.75 & 256,354 & $609 / 301 ; 609 / 463$ & Rutin \\
\hline 14 & 13.32 & 302sh; 315 & - & Hydroxycinnamic acid derivative \\
\hline 15 & 13.49 & 256,354 & $463 / 301$ & Quercetin glucoside \\
\hline 16 & 13.95 & $303 \mathrm{sh} ; 329$ & - & Hydroxycinnamic acid derivative \\
\hline 17 & 14.40 & $265 ; 348$ & $593 / 285$ & Kaempferol-3-O-rutinoside \\
\hline
\end{tabular}

\footnotetext{
${ }^{1}$ Compound number corresponds to peak number in Figure $3 .{ }^{2}$ Retention time $\left(t_{R}\right)$ of HPLC-DAD separation. ${ }^{3}$ Maximum absorption $\left(\lambda_{\max }\right)$ of UV-Vis spectrum in HPLC-DAD analysis. ${ }^{4}$ Ion pair of multiple reaction monitoring (MRM) of HPLC-MS/MS analysis.
}

The contents of individual phenolic compounds (1-16) in different growth stages of amaranth, expressed both per gram of extract and per gram of fresh matter of plant, are presented in Tables 4 and 5, respectively. Compound $\mathbf{1 7}$ (kaempferol-3-O-rutinoside) was not quantified because its content in the samples was very low $(<1 \mu \mathrm{g} / \mathrm{g} \mathrm{FM})$. The predominant compound in all samples was rutin (15.0-36.2 mg/g extract; $418-1169 \mu \mathrm{g} / \mathrm{g}$ FM), and its content consisted of approximately $95 \%$ of the sum of flavonols. Compounds $\mathbf{1 1}$ and $\mathbf{1 6}$ were the most abundant hydroxycinnamic acid derivatives. The huge amount of rutin in comparison with other phenolic compounds was in line with literature data on aerial components, especially leaves, of different species of amaranth [19,20,41]. In turn, high content of hydroxycinnamic acid derivatives with very high quantity of caffeic acid derivatives was found by Neugart et al. [18] in A. cruentus leaves. These authors reported a 3.3-3.4-fold higher content of caffeic acid derivatives than quercetin glycosides in leaves harvested at the 8-12 leaf stage. In our study, the content of hydroxycinnamic acid derivatives predominated over the quantity of flavonols in the early vegetative stage, but with a lower difference between values (718 vs. $439 \mu \mathrm{g} / \mathrm{g}$ FM). Plant growth stage significantly affected the amount of individual phenolic compounds (Tables 4 and 5). The rutin content (and sum of flavonols) increased for subsequent growth stages of plant, and the highest value was measured in early flowering and grain fill stages at the same level $(p \geq 0.05)$. Interestingly, on the contrary, the sum of hydroxycinnamic acid derivatives was found to be the highest in amaranth of the early vegetative stage, and this value decreased with age of amaranth for values expressed both on the basis of extract and fresh matter of plant. Our observation regarding the changes of rutin content during the amaranth growth cycle confirmed the trends previous reported by Kalinova and Dadakova [42]. These authors determined the rutin contents in leaves, flowers, stems, and seeds of six Amaranthus spp. (A. caudatus, A. hypochondriacus, A. hybrid, A. retroflexus, A. cruentus, and A. tricolor) and found that the rutin content in leaves was related to the developmental stage of the crop and that it usually increased with plant aging. 
Table 4. Individual phenolic compound contents in extracts of amaranth in different growth stages (mg/g).

\begin{tabular}{|c|c|c|c|c|c|c|c|c|}
\hline Comp.No & Compound & $\begin{array}{c}\text { Early } \\
\text { Vegetative }\end{array}$ & $\begin{array}{l}\text { Medium } \\
\text { Vegetative }\end{array}$ & $\begin{array}{c}\text { Late } \\
\text { Vegetative }\end{array}$ & Shooting & Budding & $\begin{array}{c}\text { Early } \\
\text { Flowering }\end{array}$ & Grain Fill \\
\hline $1^{1}$ & Caffeoylglucaric acid 1 & $0.54 \pm 0.08^{a}$ & $0.46 \pm 0.09^{a}$ & $0.45 \pm 0.01^{\mathrm{a}}$ & $0.23 \pm 0.01^{b}$ & $0.16 \pm 0.01^{b}$ & $0.19 \pm 0.06^{b}$ & $0.13 \pm 0.03^{b}$ \\
\hline $2^{1}$ & Caffeoylglucaric acid 2 & $0.77 \pm 0.19^{\mathrm{a}}$ & $0.91 \pm 0.03^{\mathrm{a}}$ & $0.83 \pm 0.06^{\mathrm{a}}$ & $0.43 \pm 0.02^{b}$ & $0.35 \pm 0.01^{b}$ & $0.26 \pm 0.15^{b}$ & $0.41 \pm 0.11^{b}$ \\
\hline $3^{1}$ & Caffeoylglucaric acid 3 & $1.33 \pm 0.15^{\mathrm{ab}}$ & $1.60 \pm 0.33^{\mathrm{a}}$ & $1.19 \pm 0.06^{b}$ & $0.59 \pm 0.07^{c}$ & $0.47 \pm 0.05^{c}$ & $0.52 \pm 0.07^{c}$ & $0.47 \pm 0.12^{c}$ \\
\hline $4^{1}$ & Caffeoylglucaric acid 4 & $1.12 \pm 0.22^{a}$ & $0.95 \pm 0.37 \mathrm{ab}$ & $1.13 \pm 0.04^{\mathrm{a}}$ & $0.60 \pm 0.01 \mathrm{bc}$ & $0.53 \pm 0.01^{c}$ & $0.40 \pm 0.01^{c}$ & $0.50 \pm 0.12^{c}$ \\
\hline $5^{1}$ & Caffeoylglucaric acid 5 & $1.70 \pm 0.17^{\mathrm{a}}$ & $1.25 \pm 0.37^{b}$ & $1.20 \pm 0.03^{b}$ & $0.60 \pm 0.01^{c}$ & $0.50 \pm 0.02^{c}$ & $0.53 \pm 0.02^{c}$ & $0.47 \pm 0.11^{c}$ \\
\hline $6^{2}$ & Coumaroylglucaric acid 1 & $0.20 \pm 0.03 \mathrm{bc}$ & $0.11 \pm 0.01^{c}$ & $0.23 \pm 0.02^{b}$ & $0.20 \pm 0.04 \mathrm{bc}$ & $0.22 \pm 0.06^{b}$ & $0.39 \pm 0.07^{\mathrm{a}}$ & $0.08 \pm 0.05^{b}$ \\
\hline $7^{2}$ & Coumaroylglucaric acid 2 & $0.61 \pm 0.14^{b}$ & $0.72 \pm 0.09^{\mathrm{a}}$ & $0.63 \pm 0.01 \mathrm{ab}$ & $0.44 \pm 0.02 \mathrm{bc}$ & $0.39 \pm 0.05^{c}$ & $0.34 \pm 0.00^{c}$ & $0.58 \pm 0.14 \mathrm{ab}$ \\
\hline $8^{3}$ & Feruloylglucaric acid & $1.00 \pm 0.07^{b}$ & $1.16 \pm 0.47^{\mathrm{ab}}$ & $1.21 \pm 0.08 \mathrm{ab}$ & $1.04 \pm 0.09^{b}$ & $1.17 \pm 0.21^{\mathrm{ab}}$ & $1.67 \pm 0.04^{\mathrm{a}}$ & $1.74 \pm 0.39^{\mathrm{a}}$ \\
\hline $9^{1}$ & Caffeoylquinic acid & $0.79 \pm 0.10^{c}$ & $0.73 \pm 0.10^{c}$ & $1.08 \pm 0.14 \mathrm{bc}$ & $0.97 \pm 0.15^{b c}$ & $1.11 \pm 0.21 \mathrm{bc}$ & $1.60 \pm 0.19^{a}$ & $1.42 \pm 0.36^{\mathrm{ab}}$ \\
\hline 10 & Caffeic acid & $0.84 \pm 0.03$ a & $0.69 \pm 0.22^{b}$ & $0.39 \pm 0.02^{c}$ & $0.20 \pm 0.01^{\mathrm{cd}}$ & $0.12 \pm 0.03^{\mathrm{d}}$ & $0.09 \pm 0.02^{\mathrm{d}}$ & $\operatorname{Tr}$ \\
\hline $11^{2}$ & Coumaroylquinic acid & $0.63 \pm 0.09^{\mathrm{a}}$ & $0.59 \pm 0.13^{a}$ & $0.57 \pm 0.10^{\mathrm{a}}$ & $0.53 \pm 0.05^{\mathrm{a}}$ & $0.44 \pm 0.06^{\mathrm{ab}}$ & $0.33 \pm 0.04 \mathrm{bc}$ & $0.22 \pm 0.03^{c}$ \\
\hline $12^{3}$ & Feruloylquinic acid & $9.89 \pm 0.07^{\mathrm{a}}$ & $5.17 \pm 1.11^{b}$ & $3.54 \pm 0.09^{c}$ & $1.27 \pm 0.03^{\mathrm{d}}$ & $0.46 \pm 0.18^{\mathrm{e}}$ & $0.39 \pm 0.011^{\mathrm{e}}$ & $0.34 \pm 0.01^{\mathrm{e}}$ \\
\hline 13 & Rutin & $15.0 \pm 1.8^{\mathrm{b}}$ & $19.7 \pm 5.7^{b}$ & $19.3 \pm 4.5^{\mathrm{b}}$ & $19.6 \pm 2.8^{\mathrm{b}}$ & $20 \pm 2.7^{b}$ & $31.7 \pm 2.7^{\mathrm{a}}$ & $36.2 \pm 8.2^{\mathrm{a}}$ \\
\hline $14^{2}$ & Hydroxycinnamic acid derivative & $1.55 \pm 0.01^{\mathrm{a}}$ & $0.69 \pm 0.17^{b}$ & $0.59 \pm 0.10^{b}$ & $0.17 \pm 0.1^{\mathrm{c}}$ & $0.23 \pm 0.05^{c}$ & $0.09 \pm 0.01^{c}$ & $0.18 \pm 0.00^{c}$ \\
\hline $15^{4}$ & Quercetin glucoside & $0.78 \pm 0.07^{c}$ & $0.86 \pm 0.21^{c}$ & $1.34 \pm 0.57 \mathrm{abc}$ & $1.23 \pm 0.15^{b c}$ & $1.28 \pm 0.03 b c$ & $1.97 \pm 0.16^{\mathrm{ab}}$ & $2.07 \pm 0.60^{\mathrm{a}}$ \\
\hline $16^{2}$ & Hydroxycinnamic acid derivative & $4.80 \pm 0.10^{\mathrm{a}}$ & $2.51 \pm 0.70^{b}$ & $2.83 \pm 0.49^{b}$ & $1.59 \pm 0.23^{c}$ & $1.11 \pm 0.27^{c}$ & $1.26 \pm 0.17^{c}$ & $1.17 \pm 0.08^{c}$ \\
\hline \multirow[t]{4}{*}{17} & Kaempferol-3-O-rutinoside & $\operatorname{Tr}$ & $\operatorname{Tr}$ & $\operatorname{Tr}$ & $\operatorname{Tr}$ & $\operatorname{Tr}$ & $\operatorname{Tr}$ & $\operatorname{Tr}$ \\
\hline & Sum of all compounds & $41.5 \pm 2.8^{a}$ & $38.1 \pm 2.7^{\mathrm{abc}}$ & $36.5 \pm 6.3^{\mathrm{abc}}$ & $29.6 \pm 3.3^{b c}$ & $28.5 \pm 3.7^{c}$ & $41.8 \pm 2.8^{\mathrm{ab}}$ & $46.1 \pm 9.0^{\mathrm{a}}$ \\
\hline & m of hydroxycinnamic acids & $25.8 \pm 1.0^{\mathrm{a}}$ & $17.5 \pm 2.8^{\mathrm{b}}$ & $15.9 \pm 1.2^{b}$ & $8.86 \pm 0.38^{c}$ & $7.27 \pm 1.03^{c}$ & $7.99 \pm 0.03^{c}$ & $7.91 \pm 1.50^{c}$ \\
\hline & Sum of flavonols & $15.79 \pm 1.8^{b}$ & $20.6 \pm 6.0^{b}$ & $20.6 \pm 5.1^{b}$ & $20.8 \pm 2.9^{b}$ & $21.2 \pm 2.7^{b}$ & $33.7 \pm 2.8^{\mathrm{a}}$ & $38.2 \pm 8.8^{a}$ \\
\hline
\end{tabular}

${ }^{1}$ Expressed as caffeic acid equivalents. ${ }^{2}$ Expressed as $p$-coumaric acid equivalents. ${ }^{3}$ Expressed as ferulic acid equivalents. ${ }^{4}$ Expressed as quercetin equivalents. Tr, traces. ${ }^{\text {abcd }}$ Means with different lowercase letters in the same row are significantly different $(p<0.05)$. Compound number corresponds to peak number in Figure 3. 
Table 5. Individual phenolic compound contents in fresh matter of amaranth in different growth stages $(\mu \mathrm{g} / \mathrm{g})$.

\begin{tabular}{|c|c|c|c|c|c|c|c|c|}
\hline Comp.No & Compound & $\begin{array}{c}\text { Early } \\
\text { Vegetative }\end{array}$ & $\begin{array}{l}\text { Medium } \\
\text { Vegetative }\end{array}$ & $\begin{array}{c}\text { Late } \\
\text { Vegetative }\end{array}$ & Shooting & Budding & $\begin{array}{c}\text { Early } \\
\text { Flowering }\end{array}$ & Grain Fill \\
\hline $1^{1}$ & Caffeoylglucaric acid 1 & $14.9 \pm 1.8^{\mathrm{a}}$ & $15.4 \pm 4.0^{\mathrm{a}}$ & $14.1 \pm 0.1^{\mathrm{a}}$ & $8.36 \pm 0.98^{b}$ & $6.36 \pm 0.54^{b}$ & $7.63 \pm 2.36^{b}$ & $4.16 \pm 0.60^{b}$ \\
\hline $2^{1}$ & Caffeoylglucaric acid 2 & $21.3 \pm 4.7 \mathrm{bc}$ & $30.6 \pm 0.9^{a}$ & $26.1 \pm 1.3^{\mathrm{ab}}$ & $15.6 \pm 0.3^{\mathrm{cd}}$ & $13.7 \pm 0.7 \mathrm{~cd}$ & $10.6 \pm 6.4^{\mathrm{d}}$ & $13.3 \pm 3.0^{\mathrm{d}}$ \\
\hline $3^{1}$ & Caffeoylglucaric acid 3 & $37.1 \pm 3.4^{b}$ & $53.4 \pm 7.9^{a}$ & $37.7 \pm 1.0^{\mathrm{b}}$ & $21.6 \pm 2.5^{\mathrm{c}}$ & $18.2 \pm 2.4^{\mathrm{c}}$ & $21.1 \pm 3.0^{c}$ & $15.1 \pm 3.3^{c}$ \\
\hline $4^{1}$ & Caffeoylglucaric acid 4 & $31.1 \pm 5.5^{\mathrm{ab}}$ & $32.2 \pm 14 \mathrm{ab}$ & $35.7 \pm 0.5^{\mathrm{a}}$ & $21.9 \pm 1.8 \mathrm{abc}$ & $20.6 \pm 1.2 \mathrm{bc}$ & $16.4 \pm 0.3^{c}$ & $16.0 \pm 3.3^{c}$ \\
\hline $5^{1}$ & Caffeoylglucaric acid 5 & $47.3 \pm 3.6^{\mathrm{a}}$ & $42.5 \pm 11^{\mathrm{a}}$ & $37.7 \pm 0.1^{\mathrm{a}}$ & $21.8 \pm 2.0^{\mathrm{b}}$ & $19.7 \pm 1.2^{b}$ & $21.6 \pm 0.9^{b}$ & $15.2 \pm 2.9^{b}$ \\
\hline $6^{2}$ & Coumaroylglucaric acid 1 & $5.46 \pm 0.07^{b c}$ & $3.59 \pm 0.04^{c}$ & $7.22 \pm 0.06^{b c}$ & $7.51 \pm 0.9 \mathrm{bc}$ & $8.81 \pm 2.5^{b}$ & $16.0 \pm 3.2^{\mathrm{a}}$ & $9.07 \pm 1.24^{b}$ \\
\hline $7^{2}$ & Coumaroylglucaric acid 2 & $16.8 \pm 3.6^{\mathrm{bc}}$ & $24.3 \pm 1.6^{\mathrm{a}}$ & $19.9 \pm 0.0^{\mathrm{ab}}$ & $16.0 \pm 2.0 \mathrm{bc}$ & $15.3 \pm 2.4^{\mathrm{bc}}$ & $13.7 \pm 0.0^{c}$ & $18.6 \pm 3.7^{b c}$ \\
\hline $8^{3}$ & Feruloylglucaric acid & $27.9 \pm 1.2^{c}$ & $39.4 \pm 15.2 \mathrm{bc}$ & $38.1 \pm 1.7^{b c}$ & $38.0 \pm 6.1 \mathrm{bc}$ & $45.9 \pm 9.5 \mathrm{bc}$ & $67.7 \pm 1.3^{\mathrm{a}}$ & $56.1 \pm 0.10^{\mathrm{ab}}$ \\
\hline $9^{1}$ & Caffeoylquinic acid & $22.0 \pm 2.3^{c}$ & $24.8 \pm 4.7^{c}$ & $34.1 \pm 3.7 \mathrm{bc}$ & $35.7 \pm 8.0 \mathrm{bc}$ & $43.3 \pm 9.5^{b}$ & $65.0 \pm 7.2^{\mathrm{a}}$ & $45.9 \pm 9.6^{b}$ \\
\hline 10 & Caffeic acid & $26.2 \pm 0.3^{a}$ & $22.7 \pm 5.8^{a}$ & $12.2 \pm 0.4^{b}$ & $7.24 \pm 0.74 \mathrm{bc}$ & $4.69 \pm 1.21^{\mathrm{c}}$ & $3.04 \pm 0.09^{c}$ & $\operatorname{Tr}$ \\
\hline $11^{2}$ & Coumaroylquinic acid & $17.6 \pm 3.1^{\mathrm{a}}$ & $20.2 \pm 5.7^{\mathrm{a}}$ & $17.9 \pm 2.8^{a}$ & $19.6 \pm 3.2^{\mathrm{a}}$ & $17.1 \pm 1.7^{\mathrm{a}}$ & $13.4 \pm 1.8^{\mathrm{ab}}$ & $7.28 \pm 0.8 \mathrm{bc}$ \\
\hline $12^{3}$ & Feruloylquinic acid & $275 \pm 4.2^{\mathrm{a}}$ & $175 \pm 48^{\mathrm{b}}$ & $111 \pm 1.0^{\mathrm{c}}$ & $46.2 \pm 2.2^{\mathrm{d}}$ & $18.1 \pm 7.5^{\mathrm{d}}$ & $15.8 \pm 0.4^{\mathrm{d}}$ & $11.2 \pm 0.3^{\mathrm{d}}$ \\
\hline 13 & Rutin & $418 \pm 40^{c}$ & $658 \pm 155 \mathrm{bc}$ & $606 \pm 129 \mathrm{bc}$ & $718 \pm 154 \mathrm{bc}$ & $780 \pm 130^{b}$ & $1286 \pm 99^{a}$ & $1169 \pm 215^{a}$ \\
\hline $14^{2}$ & Hydroxycinnamic acid derivative & $40.6 \pm 0.7^{\mathrm{a}}$ & $23.3 \pm 7.2^{b}$ & $18.4 \pm 2.8^{b}$ & $6.11 \pm 3.44^{c}$ & $9.00 \pm 2.25^{c}$ & $3.55 \pm 0.48^{c}$ & $5.88 \pm 0.30^{c}$ \\
\hline $15^{4}$ & Quercetin glucoside & $21.6 \pm 2.5^{c}$ & $29.3 \pm 8.7^{c}$ & $41.9 \pm 17 \mathrm{bc}$ & $45.1 \pm 8.6^{b c}$ & $50.0 \pm 2.9^{b}$ & $79.6 \pm 5.8^{\mathrm{a}}$ & $66.7 \pm 0.17 \mathrm{ab}$ \\
\hline $16^{2}$ & Hydroxycinnamic acid derivative & $134 \pm 5.7^{\mathrm{a}}$ & $85.1 \pm 28.7^{b}$ & $89.0 \pm 13.8^{b}$ & $58.5 \pm 12.7^{\mathrm{bc}}$ & $43.4 \pm 9.8^{c}$ & $51.1 \pm 6.5^{c}$ & $38.0 \pm 0.8^{c}$ \\
\hline \multirow[t]{4}{*}{17} & Kaempferol-3-O-rutinoside & $\operatorname{Tr}$ & $\operatorname{Tr}$ & $\operatorname{Tr}$ & $\operatorname{Tr}$ & $\operatorname{Tr}$ & $\operatorname{Tr}$ & $\operatorname{Tr}$ \\
\hline & Sum of all compounds & $1157 \pm 51^{\mathrm{bc}}$ & $1281 \pm 14^{\mathrm{bc}}$ & $1147 \pm 175^{b c}$ & $1087 \pm 196^{c}$ & $1114 \pm 181^{c}$ & $1690 \pm 101^{a}$ & $1491 \pm 270^{\mathrm{ab}}$ \\
\hline & $\mathrm{m}$ of hydroxycinnamic acids & $718 \pm 14^{\mathrm{a}}$ & $593 \pm 132 \mathrm{ab}$ & $499 \pm 29^{b}$ & $324 \pm 38^{c}$ & $264 \pm 49^{c}$ & $324 \pm 3.9^{c}$ & $256 \pm 39^{c}$ \\
\hline & Sum of flavonols & $439 \pm 42^{c}$ & $688 \pm 163 b c$ & $648 \pm 146^{\mathrm{bc}}$ & $763 \pm 163 \mathrm{bc}$ & $830 \pm 132^{b}$ & $1366 \pm 105^{a}$ & $1235 \pm 232^{a}$ \\
\hline
\end{tabular}

${ }^{1}$ Expressed as caffeic acid equivalents. ${ }^{2}$ Expressed as $p$-coumaric acid equivalents. ${ }^{3}$ Expressed as ferulic acid equivalents. ${ }^{4}$ Expressed as quercetin equivalents. Tr, traces. ${ }^{\text {abcd }}$ Means with different lowercase letters in the same row are significantly different $(p<0.05)$. Compound number corresponds to peak number in Figure 3. 


\subsection{Principal Component Analysis}

The PCA was carried out to clarify the relationship between the different growth stages of amaranth aerial parts and the evaluated variables. The data set obtained for 16 phenolic compounds, five antioxidant assays, and TPC with respect to seven growth stages was subjected to PCA. The results are presented in Figure 4. The first two principal components (PC1 and PC2) significantly explained most of the variations $-87.08 \%$ of the total variance. The clustering of growth stages with three separate groups: 1-vegetative stages (early, medium, and late vegetative), 2-shooting and budding stages, and 3-early flowering and grain fill stages was obtained as shown in plot A (Figure 4). The variables that were differentiating distribution of each growth stage were depicted in plot B (Figure 4). The early, medium, and late vegetative stages were associated with the most antioxidant assays: TEAC, FRAP, PCL-ACL, and $\mathrm{Fe}^{2+}$ chelating ability. The TPC and content of some hydroxycinnamic acid derivatives (compounds 1-5, 7, 10-12, 14, and 16) also affected this group of stages. In turn, the third group of growth stages (early flowering and grain fill) was clearly related to content of flavonols and three remaining hydroxycinnamic acid derivatives (compounds 6, 8, and 9). The DPPH assay was negatively correlated with other antioxidant activity assays because the $\mathrm{EC}_{50}$ values were used in PCA. In the plot, the DPPH assay influenced the distribution of shooting and budding stages due to their low DPPH ${ }^{\bullet}$ scavenging activity with high $\mathrm{EC}_{50}$ values.
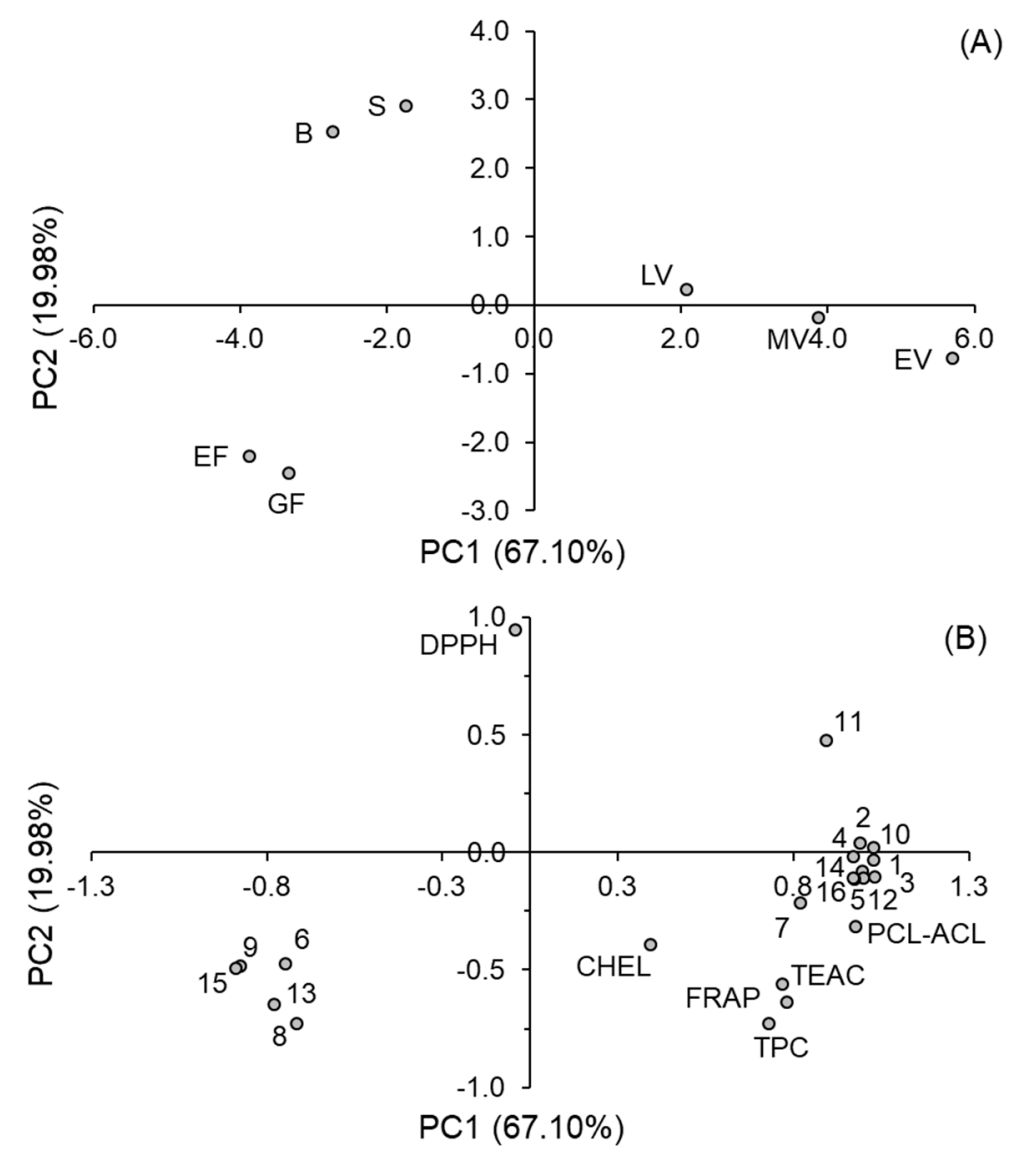

Figure 4. Principal component analysis (PCA) plots of the data set of variables: Total phenolic content (TPC), individual phenolic compound (1-16), and antioxidant assays obtained for amaranth in different growth stages. $\mathrm{EV}$, early vegetative; $\mathrm{MV}$, medium vegetative; $\mathrm{LV}$, late vegetative; $\mathrm{S}$, shooting; $\mathrm{B}$, budding; EF, early flowering; GF, grain fill; TEAC, Trolox equivalent antioxidant capacity; FRAP, ferric-reducing antioxidant power; PCL-ACL, antioxidant capacity in photochemiluminescence assay; $\mathrm{CHEL}, \mathrm{Fe}^{2+}$ chelating ability. (A): Distribution of growth stages, (B): Distribution of variables. 


\section{Conclusions}

Comparison of antioxidant activity and phenolic composition of the aerial parts of $A$. caudatus showed growth cycle dependent effects. The amaranth in shooting and budding stages had the lowest antioxidant activity and the lowest total phenolic content. The earlier (vegetative) and later (early flowering and grain fill) stages formed two groups, both with high antioxidant activity, though with differing dominant classes of phenolic compounds. The content of flavonols (mainly rutin) increased with growth cycle, and these compounds could be primarily responsible for the antioxidant activity of amaranth in early flowering and grain fill stages. In plants in vegetative stages, especially the early vegetative stage, the participation of hydroxycinnamic acid derivatives in the pool of phenolic compounds was high. The contribution of these compounds to high antioxidant activity of amaranth in vegetative stages seemed significant. It is worth noting the predominance of rutin quantity among individual phenolic compounds in all $A$. caudatus growth states, as well as its increasing content during the growth cycle.

The extracts obtained from amaranth in vegetative, early flowering, and grain fill stages, due to their high content of hydroxycinnamic acid derivatives and rutin, can be a valuable source of antioxidants that can be exploited for the production of nutraceuticals or used as a functional food ingredient.

Author Contributions: Conceptualization, M.K., F.G., R.A. and P.G.P.; methodology, M.K., G.M. and M.A.J.; formal analysis, M.K. and M.A.J.; investigation, M.K., E.L. and M.A.J.; resources, E.L. and G.M.; writing-original draft, M.K., F.G. and P.G.P.; writing-review and editing, M.K., F.G., R.A. and P.G.P.; visualization, M.A.J.; supervision, R.A.

Funding: This research received no external funding.

Acknowledgments: The Italian National Research Council provides a visiting grant to Ryszard Amarowicz in the framework of a free exchange programme between the Polish Academy of Sciences and the Italian National Research Council. The authors thank Wiesław Wiczkowski for assistance in the HPLC-MS/MS analysis.

Conflicts of Interest: The authors declare no conflict of interest.

\section{References}

1. Rastogi, A.; Shukla, S. Amaranth: A new millennium crop of nutraceutical values. Crit. Rev. Food Sci. Nutr. 2013, 53, 109-125. [CrossRef] [PubMed]

2. Repo-Carrasco-Valencia, R.; Peña, J.; Kallio, H.; Salminen, S. Dietary fiber and other functional components in two varieties of crude and extruded kiwicha (Amaranthus caudatus). J. Cereal Sci. 2009, 49, 219-224. [CrossRef]

3. Guzman-Maldonado, S.; Paredes-Lopez, O. Functional products of plant indigenous to Latin America. Amaranth and quinoa, common beans and botanicals. In Functional Foods. Biochemical and Processing Aspects; Mazza, G., Ed.; Technomic Publishing Co. Inc.: Lancaster, PA, USA, 1998; pp. 293-328.

4. Venskutonis, P.R.; Kraujalis, P. Nutritional components of amaranth seeds and vegetables: A review on composition, properties, and uses. Compr. Rev. Food Sci. Food Saf. 2013, 12, 381-412. [CrossRef]

5. López, D.N.; Galante, M.; Raimundo, G.; Spelzini, D.; Boeris, V. Functional properties of amaranth, quinoa and chia proteins and the biological activities of their hydrolyzates. Food Res. Int. 2019, 116, 419-429. [CrossRef] [PubMed]

6. Alvarez-Jubete, L.; Arendt, E.K.; Gallaghera, E. Nutritive value of pseudocereals and their increasing use as functional gluten-free ingredients. Trends Food Sci. Technol. 2010, 21, 106-113. [CrossRef]

7. Conte, P.; Fadda, C.; Drabińska, N.; Krupa-Kozak, U. Technological and nutritional challenges, and novelty in gluten-free breadmaking-A review. Pol. J. Food Nutr. Sci. 2019, 69, 5-21. [CrossRef]

8. Tang, Y.; Tsao, R. Phytochemicals in quinoa and amaranth grains and their antioxidant, anti-inflammatory, and potential health beneficial effects: A review. Mol. Nutr. Food Res. 2017, 61, 1600767. [CrossRef]

9. Alvarez-Jubete, L.; Wijngaard, H.; Arendt, E.K.; Gallagher, E. Polyphenol composition and in vitro antioxidant activity of amaranth, quinoa buckwheat and wheat as affected by sprouting and baking. Food Chem. 2010, 119, 770-778. [CrossRef] 
10. Paucar-Menacho, M.; Dueñas, M.; Peñas, E.; Frias, J.; Martínez-Villaluenga, C. Effect of dry heat puffing on nutritional composition, fatty acid, amino acid and phenolic profiles of pseudocereals grains. Pol. J. Food Nutr. Sci. 2018, 68, 289-297. [CrossRef]

11. Repo-Carrasco-Valencia, R.; Hellström, J.K.; Pihlava, J.M.; Mattila, P.H. Flavonoids and other phenolic compounds in Andean indigenous grains: Quinoa (Chenopodium quinoa), kañiwa (Chenopodium pallidicaule) and kiwicha (Amaranthus caudatus). Food Chem. 2010, 120, 128-133. [CrossRef]

12. Conforti, F.; Statti, G.; Loizzo, M.R.; Sacchetti, G.; Poli, F.; Menichini, F. In vitro antioxidant effect and inhibition of $\alpha$-amylase of two varieties of Amaranthus caudatus seeds. Biol. Pharm. Bull. 2005, 28, 1098-1102. [CrossRef] [PubMed]

13. Nsimba, R.Y.; Kikuzaki, H.; Konishi, Y. Antioxidant activity of various extracts and fractions of Chenopodium quinoa and Amaranthus spp. seeds. Food Chem. 2008, 106, 760-766. [CrossRef]

14. Peiretti, P.G.; Meineri, G.; Gai, F.; Longato, E.; Amarowicz, R. Antioxidative activity and phenolic compounds of pumpkin (Cucurbita pepo) seeds and amaranth (Amaranthus caudatus) grain extracts. Nat. Prod. Res. 2017, 31, 2178-2182. [CrossRef] [PubMed]

15. Asao, M.; Watanabe, K. Functional and bioactive properties of quinoa and amaranth. Food Sci. Technol. Res. 2010, 16, 163-168. [CrossRef]

16. Kraujalis, P.; Venskutonis, P.R.; Kraujalienè, V.; Pukalskas, A. Antioxidant properties and preliminary evaluation of phytochemical composition of different anatomical parts of amaranth. Plant Foods Hum. Nutr. 2013, 68, 322-328. [CrossRef] [PubMed]

17. Jiménez-Aguilar, D.M.; Grusak, M.A. Minerals, vitamin C, phenolics, flavonoids and antioxidant activity of Amaranthus leafy vegetables. J. Food Compos. Anal. 2017, 58, 33-39. [CrossRef]

18. Neugart, S.; Baldermann, S.; Ngwene, B.; Wesong, J.; Schreiner, M. Indigenous leafy vegetables of Eastern Africa-A source of extraordinary secondary plant metabolites. Food Res. Int. 2017, 100, 411-422. [CrossRef]

19. Li, H.; Deng, Z.; Liu, R.; Zhu, H.; Draves, J.; Marcone, M.; Sun, Y.; Tsao, R. Characterization of phenolics, betacyanins and antioxidant activities of the seed, leaf, sprout, flower and stalk extracts of three Amaranthus species. J. Food Compos. Anal. 2015, 37, 75-81. [CrossRef]

20. Steffensen, S.K.; Pedersen, H.A.; Labouriau, R.; Mortensen, A.G.; Laursen, B.; de Troiani, R.M.; Noellemeyer, E.J.; Janovska, D.; Stavelikova, H.; Taberner, A.; et al. Variation of polyphenols and betaines in aerial parts of young, field-grown Amaranthus genotypes. J. Agric. Food Chem. 2011, 59, 12073-12082. [CrossRef]

21. Conforti, F.; Marrelli, M.; Carmela, C.; Menichini, F.; Valentina, P.; Uzunov, D.; Statti, G.A.; Duez, P.; Menichini, F. Bioactive phytonutrients (omega fatty acids, tocopherols, polyphenols), in vitro inhibition of nitric oxide production and free radical scavenging activity of non-cultivated Mediterranean vegetables. Food Chem. 2011, 129, 1413-1419. [CrossRef]

22. Ozsoy, N.; Yilmaz, T.; Kurt, O.; Can, A.; Yanardag, R. In vitro antioxidant activity of Amaranthus lividus L. Food Chem. 2009, 116, 867-872. [CrossRef]

23. Miguel, M.G. Betalains in some species of the Amaranthaceae family: A review. Antioxidants 2018, 7, 53. [CrossRef] [PubMed]

24. Cai, Y.; Sun, M.; Wu, H.; Huang, R.; Corke, H. Characterization and quantification of betacyanin pigments from diverse Amaranthus species. J. Agric. Food Chem. 1998, 46, 2063-2070. [CrossRef]

25. Peiretti, P.G.; Meineri, G.; Longato, E.; Tassone, S. Chemical composition, in vitro digestibility and fatty acid profile of Amaranthus caudatus herbage during its growth cycle. Anim. Nutr. Feed Technol. 2018, 18, 107-116. [CrossRef]

26. Barba de la Rosa, A.P.; Fomsgaard, I.S.; Laursen, B.; Mortensen, A.G.; Olvera-Martínez, L.; Silva-Sánchez, C.; Mendoza-Herrera, A.; González-Castañeda, J.; De León-Rodrígueza, A. Amaranth (Amaranthus hypochondriacus) as an alternative crop for sustainable food production: Phenolic acids and flavonoids with potential impact on its nutraceutical quality. J. Cereal Sci. 2009, 49, 117-121. [CrossRef]

27. Karamać, M.; Kosińska, A.; Estrella, I.; Hernández, T.; Dueñas, M. Antioxidant activity of phenolic compounds identified in sunflower seeds. Eur. Food Res. Technol. 2012, 235, 221-230. [CrossRef]

28. Re, R.; Pellegrini, N.; Proteggente, A.; Pannala, A.; Yang, M.; Rice-Evans, C. Antioxidant activity applying an improved ABTS radical cation decolorization assay. Free Radic. Biol. Med. 1999, 26, 1231-1237. [CrossRef]

29. Benzie, I.F.F.; Strain, J.J. The ferric reducing ability of plasma (FRAP) as a measure of "antioxidant power": The FRAP assay. Anal. Biochem. 1996, 239, 70-76. [CrossRef] 
30. Popov, I.; Lewin, G. Oxidants and antioxidants part B-Antioxidative homeostasis: Characterization by means of chemiluminescent technique. Methods Enzymol. 1999, 300, 437-456.

31. Karamać, M.; Pegg, R.B. Limitations of the tetramethylmurexide assay for investigating the Fe(II) chelation activity of phenolic compounds. J. Agric. Food Chem. 2009, 57, 6425-6431. [CrossRef]

32. Peiretti, P.G.; Karamać, M.; Janiak, M.; Longato, E.; Meineri, G.; Amarowicz, R.; Gai, F. Phenolic composition and antioxidant activities of soybean (Glycine max (L.) Merr.) plant during growth cycle. Agronomy 2019, 9, 153. [CrossRef]

33. Brand-Williams, W.; Cuvelier, M.E.; Berset, C. Use of a free-radical method to evaluate antioxidant activity. LWT Food Sci. Technol. 1995, 28, 25-30. [CrossRef]

34. Janiak, M.A.; Slavova-Kazakova, A.; Kancheva, V.D.; Ivanova, M.; Tsrunchev, T.; Karamać, M. Effects of $\gamma$-irradiation of wild thyme (Thymus serpyllum L.) on the phenolic compounds profile of its ethanolic extract. Pol. J. Food Nutr. Sci. 2017, 67, 309-316. [CrossRef]

35. Stintzing, F.C.; Kammerer, D.; Schieber, A.; Adama, H.; Nacoulma, O.G.; Carle, R. Betacyanins and phenolic compounds from Amaranthus spinosus L. and Boerhavia erecta L. Z. Naturforsch. C 2004, 59, 1-8. [CrossRef] [PubMed]

36. Gai, F.; Peiretti, P.G.; Karamać, M.; Amarowicz, R. Changes in antioxidative capacity and phenolic compounds in quinoa (Chenopodium quinoa Willd.) plant extracts during growth cycle. In Quinoa: Cultivation, Nutritional Properties and Effects on Health; Peiretti, P.G., Gai, F., Eds.; Nova Science Publishers Inc.: Hauppage, NY, USA, 2019; pp. 63-81.

37. López-Mejía, O.A.; López-Malo, A.; Palou, E. Antioxidant capacity of extracts from amaranth (Amaranthus hypochondriacus L.) seeds or leaves. Ind. Crops Prod. 2014, 53, 55-59. [CrossRef]

38. Khandaker, L.; Ali, M.B.; Oba, S. Total polyphenol and antioxidant activity of red amaranth (Amaranthus tricolor L.) as affected by different sunlight level. J. Jpn. Soc. Hortic. Sci. 2008, 77, 395-401. [CrossRef]

39. Modi, T.A. Growth temperature and plant age influence on nutritional quality of Amaranthus leaves and seed germination capacity. Water SA 2007, 33, 369-378. [CrossRef]

40. Klimczak, I.; Małecka, M.; Pachołek, B. Antioxidant activity of ethanolic extracts of amaranth seeds. Nahrung 2002, 46, 184-186. [CrossRef]

41. Niveyro, S.L.; Mortensen, A.G.; Fomsgaard, I.S.; Salvo, A. Differences among five amaranth varieties (Amaranthus spp.) regarding secondary metabolites and foliar herbivory by chewing insects in the field. Arthropod-Plant Interact. 2013, 7, 235-245. [CrossRef]

42. Kalinova, J.; Dadakova, E. Rutin and total quercetin content in amaranth (Amaranthus spp.). Plant Foods Hum. Nutr. 2009, 64, 68-74. [CrossRef]

(C) 2019 by the authors. Licensee MDPI, Basel, Switzerland. This article is an open access article distributed under the terms and conditions of the Creative Commons Attribution (CC BY) license (http://creativecommons.org/licenses/by/4.0/). 